DOI 10.14746/ssp.2019.2.9

\title{
Franciszek CZECH
}

Jagiellonian University

ORCID: 0000-0001-9499-4007

\section{Saturation of the media with conspiracy narratives: content analysis of selected Polish news magazines}

\begin{abstract}
The article has three dimensions: methodological, theoretical, and empirical. A point of departure for the methodological remarks is a characterization of the three main approaches in the vibrant interdisciplinary research field dealing with the phenomenon of conspiracy theories. In this context, the content analysis method is discussed as a promising approach to gain new data on conspiracy narratives. On the theoretical level, the concept of conspiracy narratives is discussed in reference to the popular understanding of the conspiracy theory. The main aim of the empirical part is determining to what extent the media are saturated with different kinds of conspiracy narratives. The analysis covers over 200 articles from two popular Polish news magazines (Sieci and the Polish edition of Newsweek) which occupy positions on opposite sides of the political divide in a society polarized, inter alia, by a conspiratorial suspicion that in 2010 an airplane carrying President Lech Kaczyński on board was deliberately crashed in Russia.
\end{abstract}

Key words: conspiracy narratives, conspiracy theory, distrust, Poland, media, content analysis

\section{Introduction $^{1}$}

$\mathbf{I}$ $n$ the era of post-truth and fake news the phenomenon of conspiracy theory is not only a subject of interest for popular media. In recent decades it has become a vibrant interdisciplinary research field. A conspiracy theory research database run by Karen Douglas and her colleagues from the University of Kent lists 645 books and articles on the issue, written mostly in English, by anthropologists, cultural researchers, historians,

1 The first draft of this article, based on partial data, was presented at the COST Action 15101 Comparative analysis of conspiracy theories in Europe meeting at the Faculdade de Ciências Sociais e Humanas da Universidade Nova de Lisboa, Lisbon, September 22-23, 2017. 
political scientists, psychologists or sociologists and is not yet fully completed (Douglas). The growing popularity of studies on conspiracy theories seems to stem from their significance in the contemporary world. As one may read on the website of an interdisciplinary network of over 100 European researchers of conspiracy theories, run within the COST Action program: "[c]onspiracy theories - the belief that events are secretly manipulated behind the scenes by powerful forces - have a long history, and exist in all modern societies. However, their significance is increasing today, especially within Europe. They are not confined to the political margins as the product of a pathological mind-set; instead, opinion polls confirm that the majority of citizens in Europe and the U.S. now believe in one or more conspiracy theories. Some conspiracy theories may be harmless entertainment or a sign of healthy skepticism, but others are dangerous because they fuel racism, nationalism or terrorism. They can lead to political disengagement, distrust of the media, and, in the case of climate change and vaccination programs, loss of faith in medical and scientific authorities" (COST).

A review of the existing literature on conspiracy theories makes it possible to distinguish three main approaches to the problem in social sciences and humanities. The first approach is purely theoretical. The main aim here is to define and characterize the conspiracy theory and to describe analytically its features, causes and consequences. Karl Popper's conjectures on "the conspiracy theory of society," understood as the "view that an explanation of a social phenomenon consists in the discovery of the men or groups who are interested in the occurrence of this phenomenon," which is "a typical result of the secularization of a religious superstition" (Popper, 2013, p. 306), opened a whole scholarly debate on the problem and may be seen as a suitable example here. The theoretical approach is used mainly by philosophers (Coady, 2006) and to some extent by cultural researchers (Knight, 2000), political scientists (Fenster, 2008) or sociologists (Boltanski, 2014). The second approach takes a qualitative stance. It focuses on the idiographic characteristics of selected conspiracy theories. This kind of case study employs non-standardized research procedures. It is usually product-oriented, which means that it focuses not on conspiracy beliefs or thinking but on conspiracies present in cultural texts or public discourse. Case studies of a particular conspiracy theory often coexist with the theoretical approach. For instance, Peter Knight fluctuates from a general reflection on the nature of conspiracy theory to the case of JFK's assassination and back (Knight, 2000, pp. 1-116). Qualitative research on 
conspiracy is popular in culture studies (Knight, 2000) and among historians (Hofstadter, 1996), anthropologists (Astapova, 2017), and to some extent among political scientists (Fenster, 2008). The third approach to conspiracy studies is quantitative. It employs standardized procedures of experiments or survey design to generate data and seeks correlations in order to establish causal relations between believing in conspiracies and other psychological, demographic or political variables. As such, it is process-oriented and focuses not on existing texts but on conspiratorial attitudes. This kind of neo-positivist research is mainly conducted by social psychologists (Bilewicz, Cichocka, 2015) and sometimes by political scientists (Uscinski, Klofstad, 2016).

The present study employs the content analysis method to study conspiracy theories thereby suggesting another approach to researching conspiracy theories. It is an attempt to standardize the research of existing conspiracy data. Similarly to the qualitative approach, it is product-oriented research, but not a case study of a particular conspiracy theory. As a quantitative approach, it is based on standardized procedures and seems to enable tracking correlations, but, unlike typical psychological research, it uses existing data. In short, the research aims to scan selected data sets to describe and compare conspiracy narratives present within them. The possibility to compare conspiracies in different media or particular media in different countries, and to track time trends of the same media in different years - these seem to be the biggest advantages of conspiracy content analysis. Surprisingly, this kind of research has hardly ever been conducted until now. One of the very few examples might be a book, American Conspiracy Theories, by Joseph Uscinski and Joseph Parent (2014), which examined 120,000 letters to the editor of the New York Times and the Chicago Tribune from between 1890 and 2010 in order to analyze popular American tendencies and find similarities and differences in the nature of conspiracy theories over time. Another example might be an article, What about Building 7? A social psychological study of online discussion of 9/11 conspiracy theories, authored by Michael J. Wood and Karen M. Douglas. They "examined a large sample of conspiracist (pro-conspiracy-theory) and conventionalist (anti-conspiracy-theory) on-line comments on news web sites [...] and found that conspiracist commenters were more likely to argue against the opposing interpretation and less likely to argue in favor of their own interpretation, while the opposite was true of conventionalist commenters" (Wood, Douglas, 2013, p. 1). Interestingly, the data also 
indicates that conventionalist arguments tended to have a more hostile tone than conspiracist arguments.

I am neither planning to use a historical perspective like that of Uscinski and Parent, nor will I follow the path set by Wood and Douglas. I am not focused on the character or emotionality of conspiracy and anti-conspiracy arguments. Rather, I am interested in determining how many and what kind of conspiracy theories the readership or audience can come across in selected media. In other words, I plan to investigate to what extent the media are saturated with different kinds of conspiracy theories. Since the most prevalent academic writings on conspiracy theories focus on American society and culture, I have decided to examine the Polish media, which seems to be extremely interesting for the purposes of the study of conspiracy theories. In the last decade, public discourse on conspiracy theories has become a crucial part of public life. In 2010, Polish society was polarized by a suspicion that an airplane carrying President Lech Kaczyński and over ninety top officials was intentionally crashed in Russia. Conspiracy theories and accusations became an important political tool. Since 2015, the conservative Law and Justice (Prawo i Sprawiedliwość, PiS) party led by Jarosław Kaczyński, the twin brother of the president who died in the air crash, has had the majority in parliament and has been governing Poland. As we know from surveys (Czech, 2015, pp. 190-192), supporters of PiS tend to adopt more conspiratorial attitudes than supporters of the main opposition parties with a liberal inclination such as Civic Platform (Platforma Obywatelska, PO) or Modern (Nowoczesna, N). However, some research has demonstrated that opposition parties are usually more conspiracy-prone than ruling parties (Uscinski, Klofstad, 2016). Therefore, it would be interesting to explore to what extent the most popular media on two sides of the political divide are saturated with conspiracy theories.

In order to accomplish this aim, the present study is divided into three parts. First of all, in order to evaluate the saturation of the media with conspiracy theories and to decide if a claim is a conspiracy theory or not, the definition is discussed in detail. In the following section more information on the conducted research is presented. In essence, I will deliver information on the specific research problem, research sample, and procedures employed. Afterwards, I will discuss the results of my analysis. Finally, in the last section, I provide some general concluding remarks. 


\section{What is a conspiracy narrative?}

The notion of conspiracy theory is cloudy and has various meanings. Most people understand it as just "fears of non-existent conspiracies," such as Daniel Pipes (1999, p. 1), and treat them as irrational and harmful to democracy by definition. However, many scholars point out that no one is in the position to ultimately determine in every case if a particular conspiracy theory is true or false (See: Knight, 2000; Pigden, 1993; Keeley, 1999; Basham, 2003). Even conspiracies as unbelievable as Watergate sometimes turn out to be true, especially when big business and politicians are involved. Conspiracy beliefs differ widely; some appear completely unwarranted, while others just seem to be exaggerated accusations. This is just one of the reasons why conspiracy theories are no longer perceived in academic discourse just as a sign of irrational fear. Deconstruction of the classical meaning of the term, which began in the social sciences in the 1990s, also provided evidence that conspiracy theories are not necessarily harmful (See: Clarke, 2002; Raikka, 2009; Pigden 1993). Inspired by these developments, I use the notion of 'conspiracy narrative' in order to distinguish it from the popular notion of 'conspiracy theory,' and to stress the fact that I am focusing on suspicions which are not necessary false. By 'conspiracy narrative,' I mean stories that imply - contrary to widespread views - that some information regarding public matters remains hidden as a result of activities undertaken by a powerful group in order to achieve benefits at the expense of the interests of the community as a whole. In other words, this does not refer to every suspicion about secrecy, but only to an allegation that someone has broken the rules of public life for their own purposes. Thus, conspiracy narrative is understood as a distrust expressed in the public sphere, and the conspiracy in this narrative is not considered a threat to an individual, but - as Hofstadter noted (1993) - for a (political, religious or ethnic) group to which the distrusting individual belongs. This distinction is of key importance because conspiracy narratives trigger the dynamics of social activities quite differently from other types of suspicions (e.g. one that may appear among partners in a romantic relationship). This dynamic comes from the fact that conspiracy narratives not only indicate, like other types of suspicions, an entity that does not deserve to be trusted, but also unite a community that is defined as a victim. This helps to define in-groups and out-groups. The impact is strong because the suspicion is not about a lack of competence that leads to error, but about bad intentions and the deliberate violation of 
the social order. That is why, in conspiracy narratives, one can often find manifestations of indignation or pessimistic resignation among those who are convinced that the whole world is broken. Conspiracy narratives are, therefore, a form of deep suspicion focused around a serious violation of the social order. Thus, if a conspiracy theory in the popular understanding is a false suspicion, a conspiracy narrative is an important suspicion in the public sphere which might be false. Therefore, technically speaking, conspiracy theories are a subclass of conspiracy narratives.

Occasionally it is claimed that, in order to understand the meaning of the term 'conspiracy theory,' it is necessary to precisely determine what a conspiracy is. In my opinion, the word conspiracy acts as a synecdoche and symbolizes all actions to the detriment of a given group, breaking the established social order. It should be noted that conspiracy narratives express suspicion on two different levels. On the first level, it is assumed that someone has done something bad, but at the same time, on the second level, it is assumed that this fact has been and is being hidden or concealed by the media, elites or academics. In this sense, the conspiracy narrative responds in opposition to some other (usually) dominant or official narrative about a given event. It is sometimes claimed that abandoning the researcher's assessment of whether a given conspiracy theory is false results in both alternative and official explanations of something such as the $9 / 11$ attacks being treated as conspiracy theories. In one version, Bin Laden and Al-Qaeda are considered conspirators, and in the other the U.S. government is thought to organize or at least to allow the conspiracy to take place. In light of the definition of conspiracy narrative discussed here, the official statement is not considered a conspiracy narrative as long as it only refers to the causes of the attack, and it will not be argued that to divert attention from Al-Qaeda, the government is deliberately attributed responsibility. There is no such narrative, but the claim that the true role of the U.S. government is being hidden by scapegoating Bin Laden can be found. Thus, even if it is not clearly expressed, the conspiracy narrative refers not only to a specific event or state of affairs, but also tries to delegitimize other narratives about this very event or state of affairs.

So let me summarize: it does not matter whether the suspicion is true or not; it is important that it has social consequences. Here we come to the second reason why I prefer the conspiracy narrative concept. The social dynamics discussed above are possible only when certain suspicions are socially expressed and find recipients. In other words, the suspicion of someone's dishonesty must become a narrative. If someone mentally 
formulates a theory explaining some undesirable phenomenon and has not told absolutely anyone about it, this is not a conspiracy narrative yet. The concept of narrative refers to a story that has its own structure in which a negative actor appears, and is accused of some nefarious actions against the social order, thus hurting ordinary people (Kelman, 2015). Such a story may be more or less extensive, have different versions, and come across different segments of society. Of course, psychologists may find a tendency to believe in various stories about a suspicion by asking different sets of survey questions. But it is only a conspiracy narrative if it becomes a social fact.

The popular understanding of conspiracy theory is that it is "not even wrong" (Bratich, 2008, p. 3). As such, it is opposed to rationality. This opposition loses meaning if we accept the above definition of conspiracy narrative. One can imagine a scale where, on the one hand, there is rationality, and on the other, conspiratorial suspiciousness. The more distrustful someone is, the less rational. In the light of the model now under discussion, the situation is different. At the beginning of the scale is naivety, this then melts into constructive criticism of growing intensity, which then goes into deeper suspicion. Various conspiratorial claims cover a significant portion of this spectrum. Moreover, a certain amount of criticism and suspicion is also needed in public life and it is difficult to determine at what point a suspicion becomes dangerous, dogmatic, or antagonistic. $^{2}$

\section{Research design}

As has already been mentioned, the empirical aim of this article is to measure the saturation with conspiracy narratives of a given corpus of texts. More precisely, the main research problem of the current study is as follows: how many and what kind of conspiracy narratives can be identified in two Polish news magazines - Sieci and Newsweek? This problem consists of a set of specific research questions which were included in the coding scheme. First of all, some media which is full of conspiracy talk might be very critical towards it or discuss it in an ironic manner. Therefore, the second question is: what is the attitude of given media outlets toward conspiracy theory? Do they promote conspiracy narrative, or cri-

\footnotetext{
${ }^{2}$ I owe the idea of a scale metaphor to Michał Bilewicz.
} 
tique it? It should be added that, in order to promote a conspiracy theory, it is not necessary to point at somebody accusingly; suggestions or even aimless conjecture might have the same effect of promoting conspiratorial suspiciousness. The third question deals with the length of conspiracy narrative. Is a conspiracy theory only mentioned (up to two sentences), briefly presented (up to two paragraphs) or elaborated on (the main topic of the article/news)? The fourth question is: who, if anyone, is presented as the conspirator(s) in the identified conspiracy theories appearing in the media? To answer this question, a list of the most popular conspiratorial villains in the selected media will be compiled. Moreover, I plan to check how often foreign actors are cast as malevolent conspirators and how often it is an internal affair. It is an established fact that scapegoating a foreign actor might increase in-group unity, while intensively blaming internal groups might be seen as an indicator of polarization. The last research problem concerns the type of narrative, in reference to Michael Barkun's typology of event conspiracy theories, systemic conspiracy theories and superconspiracy theories (Barkun, 2003, pp. 4-6).

In order to answer the above questions, two news magazines were chosen to be examined. News magazines still remain a relatively important part of the Polish media system and have an opinion-forming character. Their readership has not dropped in the last two decades as rapidly as daily newspapers. Moreover, in 2010, sales of magazines even increased, which was interpreted as a quest for information in the turbulent time after the presidential airplane crash (Grzybczak, 2013, pp. 140-141). According to the Institute of Media Monitoring, in 2017 the most quoted news magazines were the conservative and pro-governmental Sieci and Polish edition of Newsweek, the liberal media outlet which takes a critical stance toward government (Najbardziej...). The average sale of Sieci in 2017 was close to 65,000 copies, compared to nearly 100,000 copies for Newsweek. The research has an exploratory character, and therefore only three editions of each magazine were selected for analysis. The systematic sampling method was employed. In order to avoid the seasonal specificity of topics, a five-month interval was used and the third issues of September 2017, February 2018 and July 2018 were examined. Taking into account that the saturation of each of the news magazines with conspiracy theories has not changed much from issue to issue, one can assume that the findings are to some degree representative for the period of mid-2017 to mid-2018. Nevertheless, the actual level of representativeness cannot be determined, since only three issues out of over forty were examined. 
Altogether, 203 articles, 125 from Sieci and 78 from Newsweek, were analyzed. All articles in each edition were taken into account, except advertisements.

The articles were carefully studied and all text was coded into the above sub-categories of the scheme. Although the whole research was inspired by the logic of quantitative research, at this stage the assumptions of qualitative discourse analysis were used and individual problematic statements were read in detail in context to determine, for example, whether they are conspiracy narratives or not. This was not limited to coding as a conspiracy narrative only those statements where the term 'conspiracy' or any other appears; but rather, what a given statement denotes was taken into account. Determining whether a given statement is a conspiracy narrative did not pose any problem in some cases. For example, in one of the analyzed articles, the following passage can be found: "the system of the Third Republic of Poland is a kind of oligarchy, or the rule of the few in their own interest. This system is endangered by electoral procedures because democracy formally prevails in Poland. In this situation, the oligarchy of judges remains an important element of the oligarchy, especially its last bastion, the Constitutional Tribunal. [...] So under the name of the state of law, we obtained a state of lawyers, which was such a tight corset for democracy that it really deprived it in an elementary sense" (Wildstein, 2018, pp. 8-9). This statement can be regarded as a good example of a structured conspiracy narrative in the deep state style. This was a much more difficult task in the case of shorter statements. For example, the statement that Angela Merkel "eliminated politicians, including those in her own country" sounds violent, but was considered a metaphor for taking away the influence of competing politicians, which is an acceptable element of democracy and has not been recognized as a conspiracy. There was no suggestion that the chancellor was doing something illegal and breaking the social order. At the end of the day, politicians constantly try to eliminate the influence of other politicians. Similarly, the recognition of someone as a populist was not considered a conspiracy narrative, but the belief that someone is breaking the constitution and is "introducing a crawling dictatorship" is, regardless of whether it is true or not. In such cases it is not necessary to determine if the narrative in question is trying to delegitimize another narrative (we can assume that it is self-evident that everyone denies their dictatorial impulses). Generally speaking, it is very hard to detect these kinds of delegitimization attempts since they are usually accepted tacitly as less important. Thus, conspiratorial decon- 
struction of other (official) narratives may be only a supplementary tool for determining if a given statement is part of a conspiracy narrative.

A single word was sometimes decisive for the encoding of a given statement as a conspiracy narrative. The memory of the "Smoleńsk catastrophe" was not considered an element of a conspiracy narrative, but the statement that President Lech Kaczyński died in the "Smoleńsk assassination" was treated as such. To be considered conspiracy narratives, one characteristic wording or naming was enough, just as the phrases "lone shooter," "area 51" or "truthers" refer to specific narratives with which they are inseparably linked in the social consciousness. On this basis, the naming of Lech Wałęsa with his pseudonym "Bolek" was treated as a conspiracy narrative. The term "Bolek" means not only that Wałęsa collaborated with the communist secret service, but also, in addition to sarcasm, connotes that some public actors still want to hide this fact and therefore should be loudly reminded. The truth of the claims about Wałęsa's cooperation with the communist secret service for at least some time in the 1970s, before the emergence of Solidarity, finds confirmation in historical documents (Cenckiewicz, Gontarczyk, 2008), but the narrative about Bolek also claims that he remained dependent on the secret service after the fall of communism in 1989 when he became President of Poland. This narrative, in addition to sarcasm, expresses the indignation resulting from the conviction of betrayal so characteristic of conspiracy narratives.

\section{Data and analyses}

I will begin the analysis section by reporting data on the saturation of the analyzed news magazines with conspiracy narratives. As we can learn from Figure 1, in the conservative Sieci, saturation with conspiracy narratives is twice as high as in Newsweek. In the former magazine, one can find 21.67 conspiracy narratives per issue, compared to 10 in the latter. Moreover, the narratives in Sieci are longer. In both magazines, there is a similar amount of evocations of or passing references to conspiracies (up to 2 sentences). However, in terms of briefly presented (up to 2 paragraphs) or developed stories, Sieci is more saturated. Of course, one might point out that due to the larger number of articles and pages per issue, Sieci is more saturated. This is true. If one compares the number of conspiracy narratives per number of articles, the differences seem to 
be much smaller, but Sieci (0.52) still has a higher ratio than Newsweek $(0.39)$. In my opinion, the average number of narratives per issue is a better reference point than the number of articles. This makes it possible to capture palpably the strength of conspiracy narratives to which a reader of one issue of a given periodical is exposed.

Figure 1. Number and lenght of conspiracy narrativer per issue

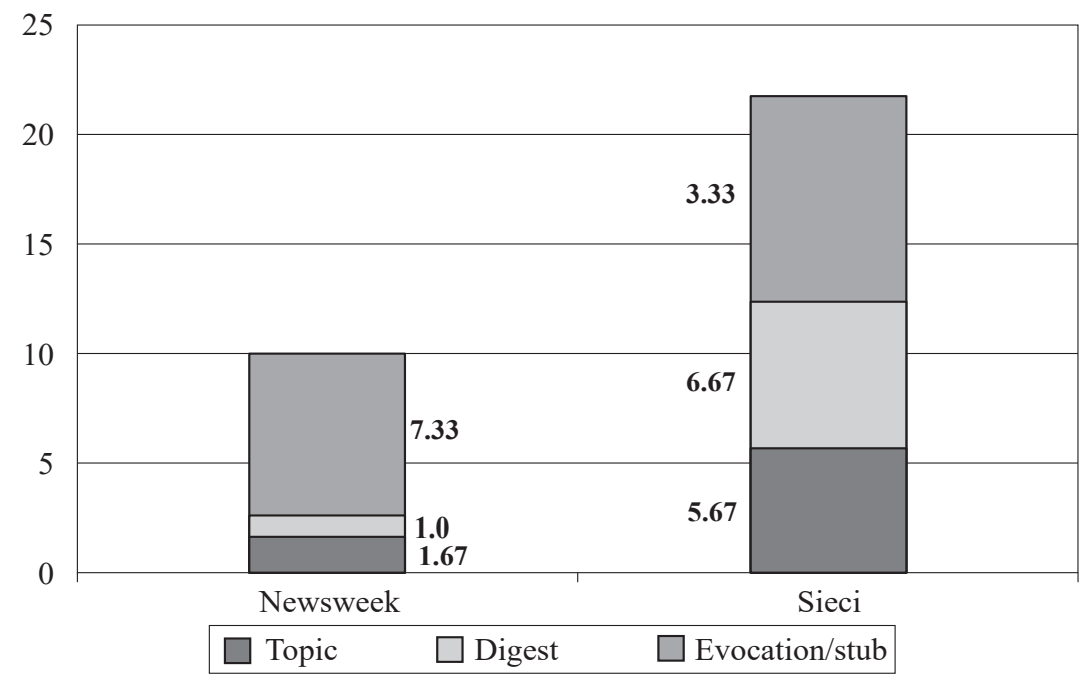

Source: Own calculation.

As expected, the data shows that saturation in comparable media outlets might be different. More research would be helpful to gain more reference points in order to better understand the meaning of the extent of the gap. In the contemporary Polish context it is also not surprising that the pro-government magazine is characterized by a higher saturation of conspiracy narratives. Usually, as some has research shown, we might expect that election losers tend to be more suspicious (Uscinski, Parent, 2014). Nevertheless, as is known from survey data, supporters of PiS, who are the target audience of Sieci, are more suspicious towards the public sphere than supporters of opposition liberal parties, which, as we might assume, prefer to read Newsweek (Czech, 2015, pp. 190-192). Based on various media effects theories, as well as empirical research on exposure to informational cues about conspiracy and political and personal predi- 
spositions (Uscinski, Klofstad, 2016), one can reach the conclusion that the more exposure to media highly saturated with conspiracy theories, the higher the individual level of conspiratorial suspiciousness. People can learn (different kinds of) suspiciousness from the media (among other things) and activate it more or less often, when the specific triggers appear. The same mechanism can be found in the concept of banal nationalism authored by Michael Billig (1998). Exposure to routine and sometimes trivial cases of conspiratorial suspicion on a daily basis (in the media and elsewhere) has an impact on attitudes toward the public sphere and its actors. Of course, Michael Billig's theory is limited by Stuart Hall's concept of oppositional decoding of media coverage (Hall, 1980). Anyway, since the media are only part of the answer, a careful measurement of media saturation with different kinds of conspiracy narratives might contribute to a better understanding of the causes of conspiracy thinking - an area dominated by psychological research on personality traits.

In the context of the above remark, the issue of one's own attitude toward conspiracy narratives seems to be important. Saturation with conspiracy narratives is one thing, and one's attitude toward it is another. As Figure 2 shows, more conspiracy narratives per volume were coded as presented favorably in Sieci than in Newsweek. As 'supportive attitude toward conspiracy narrative,' I coded cases of clear support of the narrative (declarations, providing arguments in favor of it, etc.) but also suggestions, conjectures ("it might be true") and even attempts to report its content without emotion or any consideration of its ontological status. In all these cases, a reader is prompted to assume that it might be true. In fact, only clear attempts to refute a given narrative were coded the opposite. Sieci has a much larger share of critical attitudes toward conspiracy narratives than Newsweek (29\% versus 11\%). Open critique of particular conspiracy narratives and attempts to debunk them might be a sign of mainstream depreciation of alternative and subversive visions of the social order. However, in many cases, critique is something different than scientific-based demystification of, for example, vaccine conspiracy narratives, and the more critical stance found in Sieci is not necessarily an indicator of an anti-conspiratorial or mainstream position. However, it might be assumed that this case of mainstream depreciation of a subversive narrative takes place when the share of critical attitude is high. Another hint regarding such data can be found in Steven Smallpage and his colleagues' research, where they pointed out that there are plenty of conspiracy theories which have partisan contours (Smallpage, Enders, 2017). Their 
research suggests that supporters of rival political parties can differentiate between conspiracy theories coming from members of each party and use them as calling cards that send clear signals to co-partisans. Thus, we might assume that Sieci - with a relatively high saturation of conspiracy narratives and a relatively high share of critical attitudes toward them - seems to be more involved in deep political conflict.

Figure 2. Attitudes toward conspiracy narratives

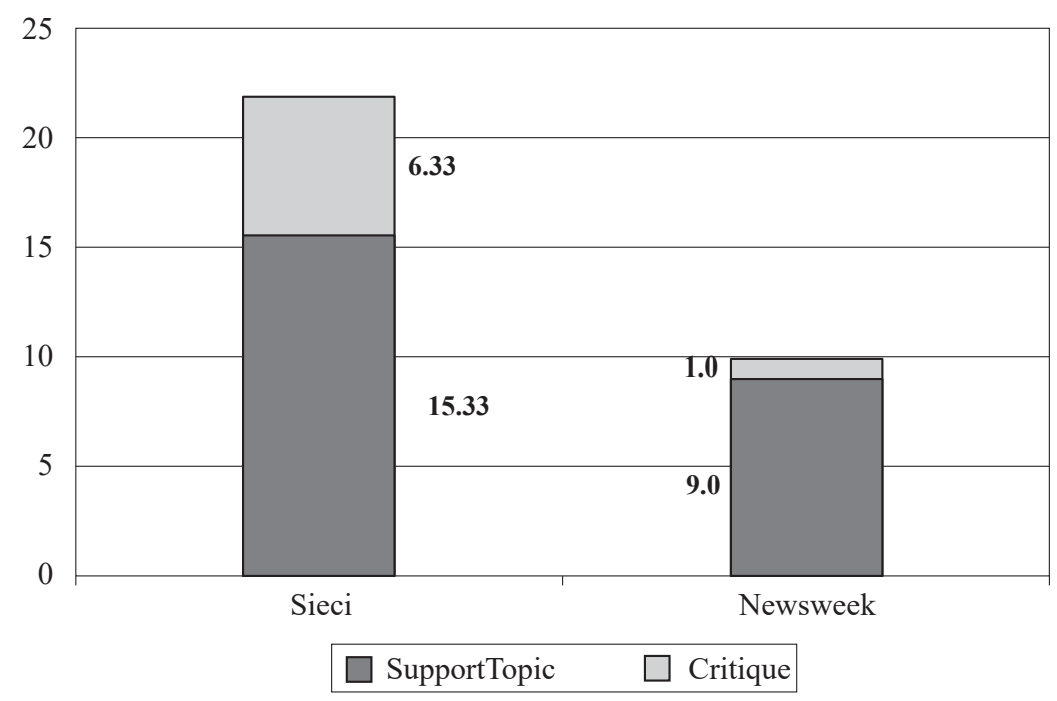

Source: Own calculation.

From now on, the analysis will skip the criticized conspiratorial narratives and move on to discussion of the promoted conspiracy narratives in both magazines in order to compare their profiles of conspiratorial distrust. The first question in this section is who, if anyone, is defined as conspirators in the narratives appearing in these magazines.

As can be seen from Figure 3, the most popular agent of conspiracy in Newsweek is the government and ruling party (four mentions per issue), while the opposition is the most popular agent in Sieci (4.67). This shows how deeply polarized Polish society is. In both magazines, the most dangerous agent is recognized within the country. Speaking of the "enemy outside," to use Jesse Walker's typology (Walker, 2013), the most feared agent is Russia. Interestingly, in both magazines one can find the same 
Figure 3. Agents of conspiracy in narratives supported by each magazine

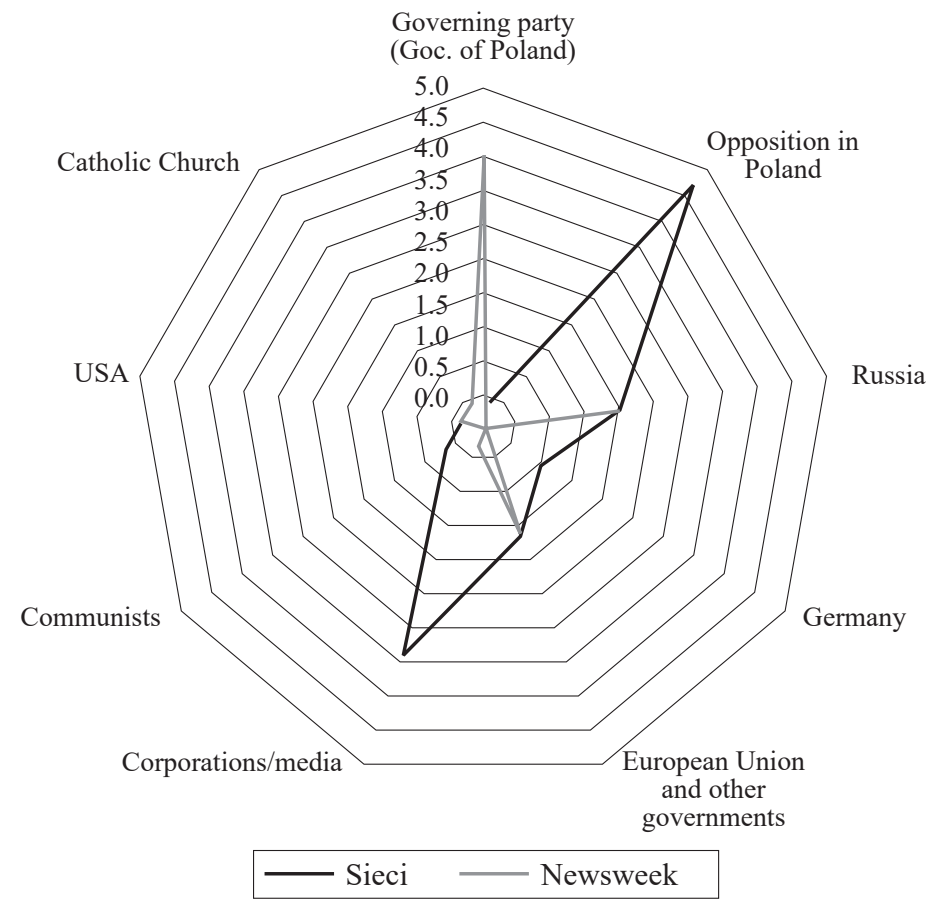

Source: Own calculation.

number of extracts defining Russia as a sinister conspirator - two per issue. Moreover, the number of conspiracy narratives devoted to the United States is also the same (0.33). The biggest difference in terms of international conspiracies is that Sieci is more suspicious toward Germany (one mention versus zero), and toward other governments and the European Union. This is no surprise considering the dispute over court reforms between the Polish government and European institutions. One could also expect that the conservative Sieci, which supports a strong state, is more afraid of corporations (3.33) and a conspiracy of former communist secret service agents and party members (0.67), while the liberal Newsweek is more scared of Catholic priests conspiring with the conservative government $(0.33)$. Perhaps it is worth noting that in the analyzed material no anti-Semitic or anti-Islamic narratives were mentioned (except one critique of an anti-Semitic conspiratorial stereotype popular in Ukraine which was 
published in Sieci in July 2018). No evidence of popular anti-scientific conspiracies, such as the dangers of vaccines or chemtrails, was found. Generally speaking, the prevailing number of conspiracy narratives in both magazines deal with the contemporary Polish political situation (sometimes in an international context).

Another way to describe a conspiracy narrative is its extent. This is closely related to the issue of victimhood. If there is a narrative about a subnational conspiracy, a local community is affected by it. In narratives on a national-level conspiracy, every citizen of the country in question is aggrieved. In the case of a supranational or global conspiracy, citizens of at least a few states suffer. For analytical purposes, one more category was added to the typology during the research. In both magazines, narratives about victims from different societies were found. The 'we' perspective is not available then, and these less emotional narratives function mainly as reports. For instance, Newsweek recounts an allegation made at a PEGIDA mass meeting that Angela Merkel had collaborated with the Stasi. Although Merkel is sometimes the protagonist of Polish narratives about her omnipotent power in the European Union, in this case she is defined as a wrongdoer in the German context and by the German political actor quoted in the article.

\section{Figure 4. Groups defined as victims in conspiracy narratives by percent of occurence in each magazine}

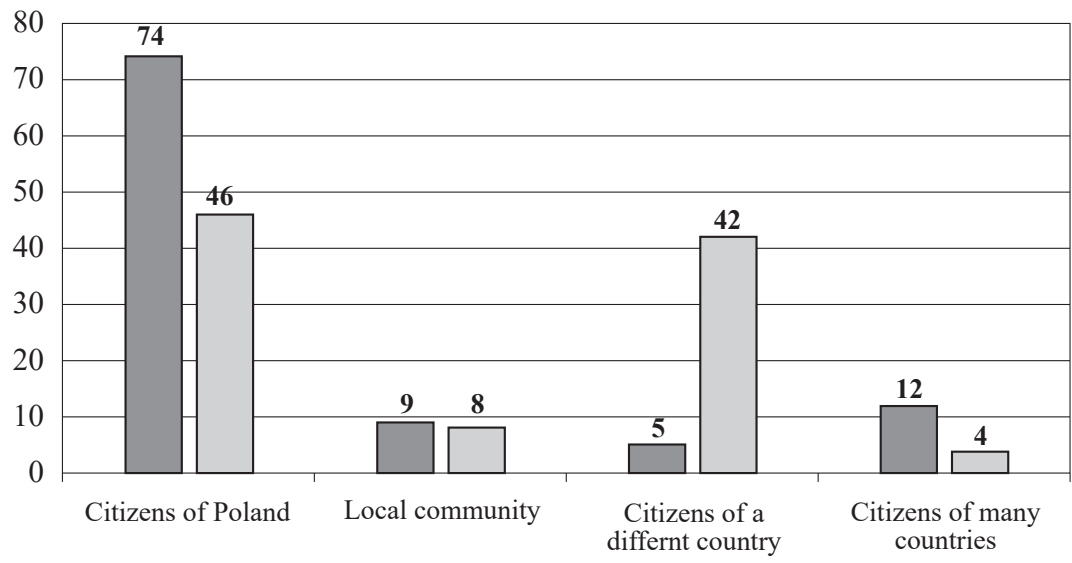

\section{Sieci} Newsweek

Source: Own calculation. 
The results presented in Figure 4 confirm that in the analyzed magazines the most popular conspiracy narratives are those dealing with threats to the citizens of Poland. Nevertheless, Sieci is, relatively speaking, much more focused on threats to Polish citizens. It is striking that $42 \%$ of the narratives in Newsweek cover conspiratorial suspicions from other countries. This reflects the fact that Newsweek has a larger international section, whereas the most developed section in Sieci is the opinion section, which is the section most saturated with conspiracy theories in both magazines. The international dimension in Sieci is presented in narratives about supposed global or supranational problems. On one hand, there are some narratives regarding the suspicious actions of transnational corporations and, on the other, about the hidden machinations of European elites against the will of ordinary citizens of European states.

Michael Barkun developed a typology of conspiracy theories: event conspiracy theories, systemic conspiracy theories and superconspiracy theories (Barkun, 2003, pp. 4-6). The first type refers to narratives about specific incidents (e.g. the Kennedy assassination). The second type is utilized in this article in a slightly different manner than in Barkun's book. Here, it refers to narratives about a persistent state of affairs in which a secret group acts against the public interest in a given state or business (e.g. the Deep State, MK-ULTRA, the Military-Industrial complex). Finally, superconspiracies are understood here as stories about a single secret power which is the only real moving force in history (e.g. the Jews, the Masons, the Catholic Church or the New World Order). This resembles the original ideas of conspiracy theory of society (Popper, 2013) and a paranoid style (Hofstadter, 1996), which deal with a belief in one omnipotent group controlling the whole world.

In both magazines the structure of the conspiracy narratives of different types is similar. The most popular are systematic conspiracies, which constitute $68 \%$ and $70 \%$ of all narratives respectively in Sieci and Newsweek. The rest of the conspiracy narratives in both magazines deal with various events. There were no superconspiracy narratives mentioned in any analyzed issue. This does not at all mean that there is no conspiracy theory like that present in Poland. This suggests that perhaps the most dangerous superconspiracy narratives - such as a holistic vision of the world based on prejudices - seem to be on the margin of public debate, and perhaps the internet is a better place to seek out these kinds of narratives rather than popular opinion-forming news magazines. Nevertheless, superconspiracy narratives seem to be relatively persistent compared to 
event conspiracy narratives, which in most cases (unless it is a very significant event such as the presidential plane crash) tend to be short-lived.

\section{Conclusion}

Content analysis of media saturation with conspiracy narratives seems to be a promising research field. It offers an alternative way to research the products of suspicious minds and to compare the saturation of different text corpuses from various states or periods. It might help to generate more general knowledge based on correlational research. Moreover, it can be applicable to monitoring media for the saturation and parameters of conspiracy narratives in order to find worrying signals. This is an important task since, as was mentioned in the opening paragraph, the issue of conspiracy theories is regularly discussed in the media as they are seen as fuel for racism, nationalism or terrorism.

Going back to the corpus of texts from the three issues published between September 2017 and June 2018 in two Polish news magazines, we might conclude that most alarming signals are not present in these mainstream and opinion-forming media outlets from opposite sides of the political barricade. First of all, there is no evidence of superconspiracy narratives. In the past this kind of conspiracy triggered violent mobilization against Jews, ethnic minorities or, in the United States, Catholics (Hofstadter, 1996). It is also worth noting that in neither Sieci nor in Newsweek was there any sign of conspiracy stereotype, understood as a holistic hostile perception of an ethnic group which points to the alleged collective goals of this group, the secret character of their collective behavior, and high levels of group egoism, reducing group members to mere executors of the collective intentions of the group as a whole (See: Bilewicz, Cichocka, 2015; Kofta, Sedek, 2005). Perhaps it should be added in this context that the February issues of the magazines were published amid emotional tension between the Polish government and Jewish and American authorities over the 'Holocaust law.' As has been mentioned, rather than proving the dangerous unification of Polish society or splintering in the face of an 'enemy outside,' such as non-Polish ethnic groups, as was popular in totalitarian regimes and less polycentric societies several decades ago, the collected data demonstrates another problem. In both news magazines, signs of the deep polarization of Polish society are evident. Polish society is deeply divided on a political level, but there is also 
a deeper conflict of social visions, which constitutes a Polish version of the so-called 'cultural wars.' Intense distrust resonates subtly in the conspiracy narratives; in Newsweek, one can find evidence of suspicion concerning priests plotting with the conservative government, while in Sieci communists and corporations (along with their neoliberal advocates) are depicted as wrongdoers. Of course, beyond partisan content, there are other differences between the two magazines, as was demonstrated in the previous section. Without doubt, Sieci is more saturated with conspiracy narrations and more focused on Polish political disputes. Nevertheless, it is hard to precisely assess if the given level of saturation with these kinds of conspiracy narratives may have serious consequences and lead to an outbreak of violent actions, or to assess what a significant increase in the level of saturation with a particular kind of conspiracy theory will bring.

Monitoring the immense volume of media texts is an ambitious task, due to the sheer quantity of various kinds of media. For this reason, creating procedures to detect the symptoms of increasing aggression towards a specific group seems difficult to imagine. This is all the more true because the same texts, as indicated the ideas of Stuart Hall (Hall, 1980), may be coded differently, and no content analysis will allow one to determine how a particular text will be interpreted, regardless of the author's intention. Definitely, more research may be helpful for a deeper understanding of the various narratives and their effects. For example, it would be worth analyzing the most popular blogs in order to better understand the differences between traditional media and citizen journalism. It would be equally interesting to compare the content of contemporary media with that from nondemocratic states in the interwar period, or to compare the saturation with conspiracy narratives of the most popular media in a given period in selected countries around the world. This would shed further light on conspiracy narratives in various media and political systems, and would provide more convincing evidence in debates about them. For example, it is often said that conspiracy theories play a very significant role in American political culture, and the United States has even been called a 'conspiracy nation' or 'conspiracy culture.' Certainly, American conspiracy theories are the most prominent because of the position of the American state, media, and universities, which contribute to the dissemination of reflection on this phenomenon throughout the world. But are the most popular American media or blogs more saturated with conspiracy narratives than, for example, those in Poland or in Arab countries? Perhaps it would turn out that, in different periods of time, different societies are more or less saturated with conspi- 
racy narratives and there is no one special conspiracy nation more prone to conspiracy theories than any other in the long run. This brings us to the second issue that media content analysis can help enlighten. This concerns whether belief in conspiracies is now ubiquitous or more marginal. On one hand, it is sometimes claimed that at present, especially during the era of universal access to the internet, conspiracy theories have become "the lingua franca" of many ordinary people (Knight, 2000, pp. 2-4). On the other hand, Daniel Pipes argues that conspiracism has become marginalized if we compare contemporary times to the interwar period, where it was the official doctrine of such states as Nazi Germany or the Soviet Union (Pipes, 1999, pp. 106-128). The analysis discussed above shows that Mark Fenster is right in writing: "[m]argins or ubiquity: in this political and cultural moment, we either face the threat that conspiracy theory will invade from the hinterlands or we must respond to the fact it has captured the popular mind. [...] I think one can marshal evidence to claim that both are correct. A relatively small proportion of Americans seems to believe firmly that a grand conspiracy is the causal engine of politics and history, while a much larger proportion of the public engages in conspiracy theory at some level, whether for pleasure or as a potential explanation for events in their lives or in the country" (Fenster, 2008, p. 2). Based on the discussed data, the same seems to be true of Poland, where superconspiracy theories were not found in the analyzed mainstream media. Nevertheless, the situation might be different elsewhere. At the end of the day, while social psychology investigations of attitudes towards conspiracy theories tell us something about people, content analysis allows us to gather what the conspiracy narratives popular in a given country tell us about that society.

\section{References}

Astapova A. (2017), In Search for Truth: Surveillance Rumors and Vernacular Panopticon in Belarus, "The Journal of American Folklore" 130, pp. 276-304.

Barkun M. (2003), A Culture of Conspiracy: Apocalyptic Visions in Contemporary America, University of California Press, Berkeley, CA.

Basham L. (2003), Malevolent global conspiracy, "Journal of Social Philosophy", no. 34 , pp. 91-103.

Bilewicz M., Cichocka A., Soral W. (2015), The Psychology of Conspiracy, Routledge, London-New York, NY.

Billig M. (1998), Banal Nationalism, Sage, Los Angeles, CA.

Boltanski L. (2014), Mysteries and Conspiracies: Detective Stories, Spy Novels and the Making of Modern Societies, Polity, Cambridge. 
Bratich J. (2008), Conspiracy Panics: Political Rationality and Popular Culture, State University of New York Press, Albany, NY.

Cenckiewicz S., Gontarczyk P. (2008), SB a Lech Wałęsa. Przyczynek do biografii, Instytut Pamięci Narodowej, Gdańsk-Warszawa-Kraków.

Clarke S. (2002), Conspiracy Theories and Conspiracy Theorizing, "Philosophy of the Social Sciences", no. 32.

Coady D. (ed.) (2006), Conspiracy Theories: The Philosophical Debate, Ashgate Publishing, Alershot.

COST, Introduction. Comparative Analysis of Conspiracy Theories in Europe, https:// conspiracytheories.eu/project-introduction/, 18.09.2018.

Czech F. (2015), Spiskowe narracje i metanarracje, Nomos, Kraków.

Douglas K., Conspiracy Theory Research Database, https://www.kent.ac.uk/psychology/people/douglask/index.html, 18.09.2018.

Fenster M. (2008), Conspiracy Theories. Secrecy and Power in American Culture, University of Minnesota Press, Minneapolis, MN.

Grzybczak J. (2013), Czasopisma i ich wydawcy, in: Polski system medialny 19892011, ed. K. Pokorna-Ignatowicz, Krakowskie Towarzystwo Edukacyjne - Oficyna Wydawnicza AFM, Kraków, pp. 123-146.

Hall S. (1980), Encoding/decoding, in: Culture, Media, Language, eds. S. Hall, D. Hobson, A. Lowe, P. Willis, Routledge, London-New York, NY, pp. 128-138.

Hofstadter R. (1996 [1964]), The Paranoid style in American Politics, in: The Paranoid style in American Politics and Other Essays, ed. R. Hofstadter, Harvard University Press, Cambridge, MA, pp. 3-40.

Keeley B. (1999), Of Conspiracy Theories, “The Journal of Philosophy”, no. 96.

Kelman D. (2015), Counterfeit Politics: Secret Plots and Conspiracy Narratives in the Americas, Bucknell University Press, Lewisburg, PA.

Knight P. (2000), Conspiracy Culture. From Kennedy to the X-Files, Routledge, London.

Kofta M., Sedek G. (2005), Conspiracy stereotypes of the Jews during systemic transformation in Poland, "International Journal of Sociology", no. 35, pp.40-64.

Najbardziej opiniotwórcze polskie media w 2017 roku, Instytut Monitorowania Mediów https://www.imm.com.pl/sites/default/files/raporty/najbardziej_opiniotworcze_media_w_2017.pdf, 18.09.2018.

Pigden Ch. (1993), Popper Revisited, or What Is Wrong With Conspiracy Theories?, "Philosophy of the Social Sciences", no. 25.

Pipes D. (1999), Conspiracy: How the Paranoid Style Flourishes and Where It Comes From, Simon and Schuster, New York, NY.

Popper K. R. (2013 [1945]), The Open Society and Its Enemies, Princeton University Press, Princeton, NJ \& Oxford.

Raikka J. (2009), The Ethics of Conspiracy Theorizing, "The Journal of Value Inquiry", no. 43, pp. 457-468. 
Smallpage S. M., Enders A. M., Uscinski J. E. (2017), The Partisan Contours of Conspiracy Theory Beliefs, "Research and Politics", October-December, pp. 1-7.

Uscinski J. E., Klofstad C., Atkinson M. D. (2016), What Drives Conspiratorial Beliefs? The Role of Informational Cues and Predispositions, "Political Research Quarterly", no. 69, pp. 57-71.

Uscinski J. E., Parent J. M. (2014), American Conspiracy Theories, Oxford University Press, New York, NY.

Walker J. (2013), The United States of Paranoia: A Conspiracy Theory, HarperCollins Publishers, New York, NY.

Wildstein B. (2018), Julia Przyłębska - Człowiek Wolności, "Sieci”, February 19, pp. 8-9.

Wood M. J., Douglas K. M. (2013), What about building 7? A social psychological study of online discussion of 9/11 conspiracy theories, "Frontiers of Psychology", no. 409.

\section{Nasycenie mediów teoriami spiskowymi. Analiza treści wybranych polskich tygodników}

\section{Streszczenie}

Artykuł ma trzy płaszczyzny: metodologiczną, teoretyczną i empiryczną. Punktem wyjścia do refleksji metodologicznej jest charakterystyka trzech głównych nurtów badawczych prowadzonych w ramach dynamicznie rozwijających się interdyscyplinarnych badań nad teoriami spiskowymi. Na takim tle omówiona jest analiza zawartości treści jako metoda badawcza pozwalająca w innowacyjny sposób uchwycić kluczowe zjawisko. W części teoretycznej przybliżona jest koncepcja narracji spiskowych w odniesieniu do potocznego rozumienia teorii spiskowych. Głównym celem części empirycznej jest określenie w jakim stopniu media są nasycone różnego rodzaju narracjami spiskowymi. Analiza obejmuje ponad 200 artykułów z dwóch opiniotwórczych tygodników (,Sieci” i polska edycja „Newsweeka”), które znajdują się po dwóch stronach politycznego konfliktu w Polsce spolaryzowanych między innymi przez spiskowe podejrzenia dotyczące katastrofy prezydenckiego samolotu w 2010 roku w Rosji.

Słowa kluczowe: teorie spiskowe, narracje spiskowe, Polska, media, analiza zawartości 
